\title{
RICKETS IN SINGAPORE
}

\author{
BY \\ CICELY D. WILLIAMS, D.M., M.R.C.P., D.T.M. \& H. \\ Lecturer in Paediatrics, King Edward VII College of Medicine, Singapore
}

Some legends die hard. "There is no rickets in the tropics.' 'There is no rickets in Singapore.' Such remarks have keen so frequently repeated that it has clouded the powers of observation. It is easy enough to produce rare cases of almost any disease, but the object of this article is to prove the prevalence of a very common disease that is responsible for a great deal of damage to child life, and to suggest the causes, and the methods of combating the condition.

Other opinions. Professor Rosedale, from the Department of Biochemistry of the College of Medicine, Singapore, basing his statements on the reports from the Medical Department for Malaya, wrote in 1934: 'Vitamin D, the anti-rachitic factor, presents no very difficult problem, as may be judged from the report of the Medical Department of the Straits Settlements for 1932, showing that out of some 50,000 admissions to Government hospitals, only two were admitted for rickets. The corresponding report for the Federated Malay States shows an admission of five cases out of some 74,000 admissions to hospital.' In 1941 Oliviero, of the same department, in 'Good Health through Feeding,' stated: 'Rickets is a comparatively rare disease in Malaya. It occurs in a mild form mainly in children of poverty-stricken parents, living in dark, insanitary cubicles.'

Kingsbury and Fasal (1940), writing from the Institute of Medical Research in Kuala Lumpur, F.M.S., found many cases of rickets in Tamil children. Miss I. M. M. Simmons, Matron of the welfare work in the rural areas of Singapore Island, recognized many cases of rickets among the children and stated as much in a report published in 1934, but the doctors did not investigate these cases.

Geography. Singapore Island is about 25 by 20 miles in extent. The town lies some three degrees north of the equator. In 1939 the population was over 700,000 , of whom some 600,000 lived in the municipal area. The climate is warm and damp, the rainfall rather heavy and so regular that the island is perenially green and florid. Malaria used to be a fearful scourge, but is now well under control. The major epidemic diseases, such as cholera, plague and smallpox are now practically unknown.

Population. The Chinese represent over 80 per cent. of the population, and control most of the commerce, the coolie labour, and the farms and vegetable gardens in the rural areas. Indians, mostly Tamil labourers, but including some Sikhs and Bengal and Bombay merchants, form some 8 per cent., while 'Malays' (who are mostly in fact Javanese and Boyanese) another 9 per cent. The remaining 3 per cent. consists of Europeans, Eurasians, Jews, etc. The industries were mainly concerned with the handling of tin and rubber and pine-apples for export. There were some factories for local consumer goods. The 'Straits born' Chinese, some of the Malays and the Eurasians are the truly indigenous, and they only form a small proportion of the total population. The other inhabitants are mostly male, mostly between 25 and 50 years of age, and mostly come to Malaya to find work. If they can they will return to China, to India or to Europe when they are old, with or without a fortune.

Social services. There were several well-equipped modern hospitals. The Chinese, Indians and Eurasians came to hospital fairly readily, but the Malays were conservative and were rarely willing to accept western methods, although they were the only members of the population who received free education.

The General Hospital had two wards accommodating 120 children under six years old. They admitted about 3000 cases per annum, and the teaching on paediatrics was done in these wards. The mortality amounted to nearly 50 per cent. of admissions, as the babies were very frequently brought in moribund-merely to avoid funeral expenses in a poor household. It is hard to break a vicious circle; on account of the large proportion of deaths many people were unwilling to have their children admitted. Unfortunately the wards were not associated with the out-patient department, nor with a system of home visiting, and therefore any sort of follow-up work was difficult. The municipal welfare service was only extended to babies under one year of age, though with the rural welfare service it was possible to obtain excellent co-operation. On the whole, therefore, paediatric experience was overweighted with moribund medication and morbid anatomy.

Economic background. Most of the children come from the poorer classes. The father is a coolie getting 10 to 20 dollars per month. (One Straits Settlements dollar equals two shillings and 
fourpence.) He lives with a wife and a few children in a cubicle 8 by 10 feet, for which they pay 3 to 5 dollars per month. The father has periods of unemployment or he may have expensive habits, such as opium smoking and gambling. The mother has to make something extra by working as a coolie, in a factory, by domestic help, or as a hawker. The children are left in charge of some indigent old woman, or else left locked up in the cubicle while the parents are out. The baby is hung up in a sarong from the roof. The younger children may scarcely ever go outside. The cubicle may be on the second or third floor-one of eight running from back to front of the house. Only the cubicles at the two ends of the row have any windows. It is reached by flights of narrow stairs. Perhaps as many as thirty other families live in the house. On the ground floor is the only latrine, of the bucket variety. The only cooking place is next door to it. The only water supply is a tap on the ground floor.

Rice is the staple diet, generally polished rice, and some salted vegetables imported from China, with, occasionally, dried fish and a little pork. Greens are eaten whenever possible. Old people go through the rubbish bins and pick out the discarded cabbage leaves. They tear out the bruised portions, and sell what they have salvaged at one cent. a handful. Unpolished rice can be bought, but the cheap varieties are full of broken and unhusked grains, so that it gives rise to enteritis unless it is picked over. It takes longer to cook than the polished, so that it costs more in fuel and time spent than the polished variety. Cooked food is often bought because of the saving of time, fuel and trouble. If the mother is ill or pregnant, even the small children are given a few cents to buy food from hawkers or at the numerous chop-houses.

Children are usually treated with affection, but the practical expression of affection is strictly limited by economic considerations, and by profound ignorance of hygiene. Babies are a luxury-highly valued if you can afford them. Babies that are unwanted may be sold or given away or abandoned. In spite of the large excess of males over females among the immigrant population (about 100 to 70 ) girls are still regarded as undesirable. In one year 575 unwanted babies were left at the Convent of the Sacred Heart. Of these only thirteen survived.

Nutrition of children. Beri-beri and tuberculosis are rampant. Malnutrition exists in every degree and in nearly every form. Nearly all cases admitted to the wards are due to, or complicated by, some sort of malnutrition, whether it be due to faults in the choice, in the preparation, or in the consumption of food.

Some cases of malnutrition are dramatic and well defined, while many are vague and subclinical. The diseases due to food deficiencies are of comparatively recent interest, and much remains yet to be known about the vitamins and the conditions resulting from the lack of them. It is a mistake to think that the natives of a country are those who know how to make the best use of its resources. Malays and Chinese, Tamils and Eurasians, and Europeans as well, all have their misguided and disastrous ideas about food and about the care of children. As the majority of the Singapore population is Chinese, it is to them chiefly that these remarks apply.

Considering the wealth of the place, the absence of epidemics, the healthy climate and good water supply, the infant mortality is excessive.

\begin{tabular}{|c|c|c|c|c|}
\hline INFANT & MORTAL & TY F & TES & \\
\hline & 1937 & 1938 & 1939 & 194 \\
\hline England & 58 & 53 & 50 & \\
\hline Singapore, rural area & 103 & 104 & 68 & \\
\hline $\begin{array}{c}\text { marea } \\
\text { are, municipa }\end{array}$ & 171 & 177 & 147 & 160 \\
\hline
\end{tabular}

It is probable that this excessive infant mortality rate is due to malnutrition more than to any other factor, as the mortality rate for children of over one year is not high. Malnutrition results from ignorance and poverty, and the particular ways in which these factors manifest themselves are in artificial feeding, including improper substitutes for breast milk, in bad housing conditions and in wrong methods of child management.

Artificial feeding and social customs. Although the Indians as a whole are poorer than the Chinese, they have the smallest infantile mortality rate. They are the only race that adopts breast feeding as a matter of course.

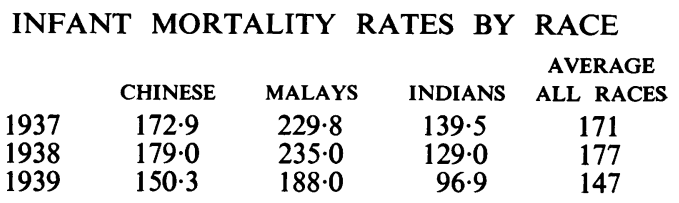

Artificial feeding is a serious problem among the wealthy Chinese. Among the poorer classes it is a fearful scourge. The wealthy Chinese often give out their babies to a foster-mother to wet or dry nurse. The educated and semi-educated give all manner of excuses for not breast feeding the baby. The following are some of the reasons for artificial feeding:

(1) The Chinese despise the normal female figure, and the women wear tight bodices which produce atrophy of the breasts and depressed nipples. This is, racially, far more damaging than the custom of binding the feet. It is remarkable that it has received so little notice from their national leaders.

(2) The mother has to go to work and the baby is left at home in charge of some other child or some old woman.

(3) The mother is sick and cannot feed the baby. Malnutrition, especially that leading to beri-beri, is exceedingly common and has an adverse effect on lactation.

(4) The grandmother, or the senior wife, or some other relative wishes to take control of the baby.

(5) The people are poor, and the baby is sold to someone else, or given away to a relative who is 
better off or who has fewer children. If the baby is sold, the transaction must take place through a recognized 'go-between.' The price varies very much. It may be over 300 dollars for a healthy little boy, whereas a sickly girl might be given away with a dollar or two to boot. There are some people who definitely gamble in children. They will go to the mother of a sick child and say, "This baby isn't much good. It will probably die. I'll give you a dollar for it.' The child is sold, and often it is brought to the hospital. If it dies, the dollar is gone, but if it recovers, then it is sold again at a much higher price. One baby we admitted had been exchanged for $6 \frac{1}{2} \mathrm{lb}$. of rice, mee and pig's trotters. Frequently a girl is bought or adopted as the prospective wife for $a$ boy in the family, or as a 'Mui Tsai.' It is hard to understand why these ' little sisters' have been so singled out for attention by reformers. As a matter of fact they only form a small detail in a complicated and often distressing social picture. But the distressing features arise from generalized ignorance, poverty, dirt and exploitation, not from the custom of adopting Mui Tsai. It is fashionable among wealthy Malays to buy a little Chinese girl. They are brought up as household attendants, and marry into the Malay families. They are thus acquiring merit by bringing unbelievers into Islam, and 'whitening up' the family complexions.

(6) With the existing reluctance of the Chinese to breast-feed their babies there is the natural corollary of poor technique in the management. It is remarkable to see how unwise and how unhandy a Chinese woman may be in matters pertaining to mothercraft. This applies to every class, from the towkays to the coolies. Added to the poor technique there is the misguided popularity of sweetened condensed milk. The palatable sweetness of this, when it is once started as a supplementary or as a complementary feed, often results in the baby refusing to take the breast, or taking the breast with no enthusiasm and finally in the drying up of the milk. With wearisome and deadly frequency one hears 'the baby would not suck,' ' the breast milk disappeared in three weeks,' and in every case it is proved that sweetened condensed milk had been given.

(7) The advertisements of the milk firms are responsible for a certain amount of misguided propaganda. The people they employ are not always wise in their methods and it may be found that artificial feeding and infant mortality are higher in those areas where milk firms have their 'nurses' working than in those where they do not.

(8) Among the school-teacher and shopkeeper class, where the mother is a worker, artificial feeding for the infant will enable her to continue with her occupation. The mother's understanding of child management is exceedingly imperfect owing to the defects of our educational system. In the Government service women are only given two to six weeks leave after confinement, so they cannot breast-feed their babies and retain their posts. This regulation has done much to encourage artificial feeding and to damage child life.

Method of artificial feeding. The above eight clauses are the most important in explaining the prevalence of artificial feeding. We should now examine why it is so particularly harmful.

(1) The sanitary standards of the population are low. Housing conditions are often bad, and the almost universal prevalence of the round worm is some indication of the unhygienic habits. Cases of ascariasis have been found as young as three months of age. Most households are incapable of preparing a baby's feed in even a remotely sanitary manner.

(2) The wages earned by the average household make it difficult or impossible for them to buy tinned milk in sufficient quantities to feed the baby adequately. The result is that the sweetened condensed milk is often diluted to one in thirty (instead of one in six or eight). It is often mixed with rice or wheat or cornflour, which may or may not be properly cooked before it is given.

(3) If the baby is not fed by the mother he is often left to the care of someone less capable of looking after him.

(4) If sweetened condensed milk is used for infant feeding over a long period', the baby needs plenty of sunshine and additional supplies of vitamins, especially of the fat-soluble vitamins. There is only a very small percentage of the population in Singapore who attend welfare centres or orthodox doctors regularly, and few indeed that receive cod liver oil as part of their diet.

SWEETENED CONDENSED MILK. The artificial feed that is by far the most widely used is sweetened condensed milk. It is well known that this can be a most useful infant food, but that if continued as the only food over a long period it tends to make the child fat and flabby, subject to boils, to diarrhoea and catarrhs and to rickets. Happily the only sweetened condensed milk that is permitted for sale by the Government is the full cream variety. But this is often diluted so much that it is a poor diet. Even the orthodox mixture of one in six or one in eight is very poor in fat.

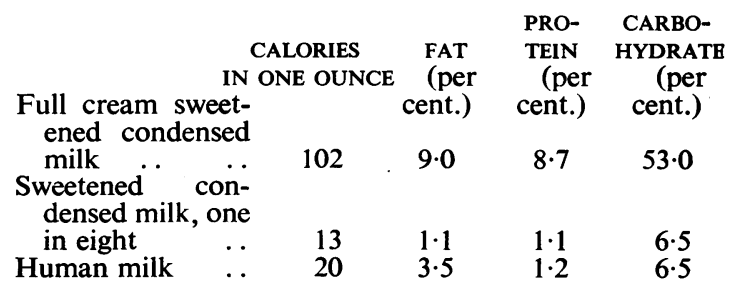

The poor fat content is not the only disadvantage of this mixture. There is also a shortage of the fatsoluble vitamins. Different brands of tinned milk are sold at widely different prices, although they all give approximately the same analysis. Generally speaking the more expensive brands were those prepared from meadow-fed English cows in the summer and from meadow-fed Australian cows in 
the antipodean summer. The cheaper brands came from stall-fed cows, generally Dutch and Danish. Professor Rosedale kindly estimated the Vitamin A content of the cheaper brands and the figures for vitamin A proved to be extremely small. This investigation was undertaken after it had been noted that of thirty consecutive admissions of babies blind or partially blind from keratomalacia, 28 had been fed on sweetened condensed milk. It will be seen that rickets also is prevalent among babies fed on this milk.

Etiology and diagnosis of rickets. Rickets is produced by two major and is associated with two minor factors. The major factors are (1) improper feeding, and (2) insufficient sunlight. The minor factors are (1) prematurity, and (2) congenital syphilis.

Both the minor factors are easy to eliminate. Prematurity can generally be excluded by reference to the history (and the welfare card), and congenital syphilis by blood tests on the baby and its parents and by x-ray appearances. It has been found that these minor factors are only associated with a very small proportion of the cases of rickets.

When considering the diagnosis and the importance of rickets in this place there are various points to bear in mind :

Rickets is primarily a disease of growth. Where malnutrition leads to defective growth, then rickets is only seen in minor degree. In many of the babies with whom we were dealing the total quantity of nourishment received was so very small that the degree of rickets was comparatively inconspicuous. Malnutrition may be so severe that at two and three years old the child only weighs 12 to $14 \mathrm{lb}$. These are not the children one sees running about in the streets, and children over one year are not visited by the Municipal Health Nurses, so that it is only when they are brought to the hospital (and that is often only when they are moribund) that the disease is seen. Minor degrees of rickets in an ill-nourished child are just as significant as florid rickets in a well-grown child.

The popular diet is poor in calcium. The early osseous changes in rickets result from an absence of lime salts in the more recently formed parts of the bony skeleton. These do not necessarily (per se) harm the child. But even mild degrees of bony changes may be accompanied by a serious predisposition towards catarrhal conditions of respiratory and digestive tracts. These are the results of rickets that endanger life.

Conditions which lead to the appearance of rickets, and the anaemia which invariably accompanies rickets, are those conditions which result in a high rate of infantile mortality and morbidity.

The presence of rickets is generally proved by $x$-ray appearances. It must be remembered that there are many early cases in which, if a post mortem is done, rickets can be recognized in histological sections, whilst the condition is as yet too early to show radiographical changes.

There are many children who show slight beading of ribs and early radiological changes in whom there is no evidence of illness or of any general disturbance. These cases are common among a well-cared-for population. But in the stress and strain of slum life in Singapore it appears that very mild signs of rickets may be associated with catarrhal conditions which prove fatal.

The subject of rickets has not in the past been brought to the attention of the medical authorities in the locality. Although cases were constantly treated in the hospital from among babies attending welfare centres in the town, it was not a disease that was ever diagnosed by the staff of these centres, and there were many doctors who disputed the existence of the condition. It had, however, been recognized by Matron Simmons in the rural areas.

In this paper cases are only classified as rickets if the diagnosis was confirmed, either by $\mathrm{x}$-ray or by post-mortem appearances. In addition to these there were numerous cases, especially among those that died very shortly after admission and before they could be investigated, in which signs of rickets were forgotten or unidentified behind a fulminating secondary condition, such as enteritis, meningitis and pneumonia, so that the real incidence of the disease is probably larger than that shown in the figures given in the appendix.

Age of incidence. In wards for children up to six years of age it was found that most of the cases of rickets were in children who were between three and sixteen months of age. It was not uncommon as early as six weeks. This is early compared with the age of incidence in other countries.

It is rare to see cases of genu valgum or contracted pelvis or any evidence of rickets in the adult population. This is because the disease is limited by the social and domestic conditions already described. The babies and children often live inside dark stuffy cubicles. If they get rickets they may die from some intercurrent disease. If they survive the first year or two of life, then they go outside and the progress of the disease is automatically arrested by the strong sunlight.

Race. The majority of the cases we saw were among artificially fed Chinese babies. Chinese formed about 90 per cent. of the children in the wards. Among the small number of Indians admitted to the wards, nearly all were breast fed. Some very severe cases of rickets were met in breastfed Indian babies. These were mostly among the Sikhs, who live a semi-purdah life. It is recognized that the pigmentation of the skin favours the development of rickets if the other factors are present.

Clinical picture. BEaded RIBS. This was found to be the earliest and most reliable sign. Any baby that on palpation showed signs of irregularity along the costo-chondral junction was investigated for rickets. In fat babies it was impossible to see, and often difficult to feel, this beading. Marked beading was invariably accompanied by advanced radiological changes. 
ENLARGEMENT OF EPIPHYSES. This is generally noticeable at wrists and ankles.

Craniotabes. Park and Eliot (1933) state that craniotabes is often the first definite sign of rickets. This observation in Baltimore has not been confirmed in Singapore. No single case of craniotabes has been met with, although it has been faithfully sought for in every child.

Bossing OF THE HEAD. Few well-marked cases are seen, possibly explained by the unusually early incidence of the disease.

Deformities OF THE LIMBS. These are also rare in any marked degree, but this is only to be expected as the story-book deformities do not generally appear until the limbs begin to bear the weight.

ATONICITY OF MUSCLES AND LAXITY OF LIGAMENTS. These are often well marked. They produce ' the belly of the poisoned pup,' marked kyphosis, lateness in walking and genu recurvatum. Generally, flaccidity is increased by the other dietetic defects, such as beri-beri and underfeeding.

SWEATING OF THE HEAD is not conspicuous as a symptom. Sweating, sudamina, and septic skin conditions are excessively common in any case.

ANAEMIA. The average haemoglobin for children in Singapore is well below the ' normal' in London. But in cases with rickets it was generally found that the anaemia was more conspicuous-even profound. It was of the usual secondary type.

DenTAL CARIES. The Chinese, as a rule, have very bad teeth. Ricketty Chinese children showed the delayed dentition and dental caries that are typical of rickets. But among the Indian children, who were incidentally nearly always breast fed, it was found that even a case of 'gross rickets' might have a perfect set of teeth.

SPLENOMEGALY. This was generally slight and often absent.

SECONDARY INFECTIONS. As our cases were limited to those admitted to hospital it was not possible to estimate the number of children among the general population who showed signs of rickets without other symptoms. But it appeared from our purely institutional experience that those who showed x-ray evidence of rickets were subject to high morbidity and mortality from gastritis, enteritis, convulsions, otitis, meningitis, septic skin conditions and respiratory disturbances.

Convulsions. These are very frequent and will be referred to under ' Rickets with tetany.'

Pathology. Biochemical examination was not always possible owing to the condition of the patients and also to the shortage of staff.

Plasma phosphatase is usually considered the most accurate indication of the degree of rickets. Unfortunately for lack of the necessary reagents we were unable to carry out this estimation.

Blood Calcium. Normally this is 10 to $12 \mathrm{mgm}$. per cent. In rickets it may be normal, but in 'low calcium' rickets it may be reduced to as little as 4 per cent. and these cases are often accompanied by signs of tetany and cerebral irritation. This is typical of the findings in Singapore.
SERUm PHOSPHORUs. This is usually $5 \mathrm{mgm}$. per cent. and in rickets may be reduced to 3 to 3.7 per cent. This was also mainly confirmed.

CAlCIUM PHOSPhorus MUltiPle. It has been said that $\mathrm{Ca} \times \mathrm{P}$ should be 40 or over. It was found in practice that many a child with a multiple of well over 40 still suffered from undoubted rickets.

Radiology. The radiological changes were in no way different from those generally seen. The presence of subperiosteal osteoid tissue was often a prominent feature, and sometimes appeared before the other bony changes. At first some difficulty was experienced in persuading other doctors that this feature (i.e. described as periostitis in the X-ray reports) was not necessarily a sign of congenital syphilis. In fact there is usually a considerable difference between the coarse, irregular periostitis of syphilis and the regular, delicate, symmetrical 'subperiosteal osteoid' of rickets. The former is also usually accompanied by irregular thickening of the bones, which is not present in rickets.

Malnutrition is exceedingly common, and besides predisposing towards deficiency diseases, of which beri-beri is by far the commonest and rickets the next, the diet is conspicuously poor in calcium. A great many $x$-rays, besides those that show rickets, show bones that are poorly calcified. The poverty in calcium, probably in combination with other deficiencies, appears to alter the maturation of the bones, producing some premature ossification. It has been observed that the 'radiological age' of young girls is often two or three years in advance of the age given on their birth certificates. It is inviting to postulate a theory that the anaemia which is always found in rickets, and which is so terribly common and intractable in many Asiatics, may be associated with faulty development, not only of the calcified parts of the bone, but also of the blood-forming organs of the marrow.

Morbid anatomy. We were able to obtain a large number of post mortems, and to confirm the usual findings, both gross and microscopic. Many cases showed histological evidence of rickets, appearing first at the costo-chondral junction, where there was only slight beading present, while the x-ray appearance was still negative: e.g. Case No. $2353 / 40$ (1940 series).

This was a Chinese female infant of two months old, fed from birth on sweetened condensed milk. The infant was admitted with fits. There was beading of the ribs and both $\mathrm{Ca}$ and $\mathrm{P}$ were low $(8.5$ and 3.7$)$. The $x$-ray showed little evidence of rickets, but after the post mortem, sections of the costo-chondral junctions showed rachitic changes, which were absent in the femur.

The periostitis of congenital syphilis showed round-celled infiltration which distinguished it from that of rickets.

Types of rickets. Rickets With TETANY. Cases with fits were often associated with a low blood calcium, e.g. table 2, cases 1647, 1898, 1987, 2004, 2021, 2083, 2196, 2345, 2353, and 2359. 
'Infantile convulsions' is given as a cause of death in a very large number of babies in the Singapore statistics-especially in cases which have not attended the hospital and therefore are unlikely to be accurately diagnosed. It is probable that a large proportion of these fatal cases of convulsions are associated with tetany, with or without rickets

Convulsions are exceedingly common in babies, and calcium deficiency is an important one of the many causes. Subacute cases of beri-beri are often associated with convulsions and head retraction (cf. the experimental pigeon rather than with beri-beri in adults). Nutritional disturbances, helminthiasis, particularly ascariasis, and meningitis are all excessively common. Calcium deficiency and tetany are not yet sufficiently widely recognized as a cause of convulsions and often even if it is suspected, the calcium given in treatment is not sufficient to correct the deficiency, e.g. Case 2644 (1940 series):

Chinese male, aged three months. Breast fed one week, then given sweetened condensed milk; admitted to another ward with severe convulsions. Was treated with intramuscular calcium gluconate solution 10 per cent. $2 \mathrm{c.cm}$. daily. The cerebrospinal fluid was found to be normal. The fits persisted and three days later the infant was transferred to the writer's wards with a diagnosis of 'encephalitis.' The convulsions were still persistent and violent. The blood calcium was then estimated and proved to be $5 \mathrm{mgm}$. per $100 \mathrm{c.cm}$. and the phosphorus 6.5 per $100 \mathrm{c} . \mathrm{cm}$. The calcium gluconate solution was increased to $10 \mathrm{c}, \mathrm{cm}$. twice daily and was accompanied by adexolin and calcium by mouth. At once the child improved and was discharged fit in a short while.

RICKETS IN PREMATURE BABIES. This type of rickets was severe and obstinate and apparently could not be prevented by any means at present at our disposal. Premature babies, if they were kept inside the ward, invariably became rickety, and even if they were nursed systematically on the balcony, they still developed a mild degree of osseous rickets, although the secondary catarrhs might be comparatively mild or absent. The climate is warm throughout the year so that they had little or no covering, and were only brought inside on account of rain. It appeared that Indians, with skins more deeply pigmented, were more prone to this type of rickets than the Chinese, e.g. Case No. 1769 (1940 series):

Chinese female, aged six months. Birth weight $2 \mathrm{lb} .6 \mathrm{oz}$. Had been breast fed and well cared for, and visited regularly by a health nurse, but had not been given any vitamin $D$. At six months the infant weighed $8 \frac{1}{2} \mathrm{lb}$. Beading of the ribs was well marked. X-ray report stated 'gross rickets.' The infant developed diarrhoea and pneumonia and died.

Rickets With CONGENITAL SYPHILIS. The incidence of congenital syphilis in Malaya has been wildly overestimated. The statement that 'fifty per cent. of the babies suffer from syphilis' has actually been made by individuals who should be counted as responsible. In actual fact, less than 3 per cent. of the sick children admitted to our wards showed any evidence of syphilis. It is true that there is a great deal of venereal disease in the adult population, both in town and country areas. But it must be remembered that social and economic conditions have produced a section of the population that is predominantly male, that comes to this country in order to make money and then return home to another country. This is the population which does not breed, but in whom syphilis is rampant. The other section of the population that settles down and makes its home here, and which does breed, has relatively little venereal disease. At Tan Tock Seng, the large male hospital, in taking histories one often gets the reply "No, I have not got venereal disease, I am a married man.' (This is another illustration of the desirability of cultivating a 'Straits born' population, rather than tolerating the large infant mortality and then depending on labour that has to be imported.)

Cases that have formerly been called syphilitic are mostly nutritional deficiencies and marasmus. In rural areas where yaws is prevalent the majority of the positive W.R. and Kahn tests are due to yaws and not to syphilis. Among 2000 admissions (table 1) there were nineteen cases of congenital syphilis, of which four were proved to have rickets as well. It would seem that the incidence of rickets among congenital syphilitics is high.

OBSTINATE RICKETS. Cases of rickets have been described which persisted in spite of every known form of treatment. These were not encountered in our experience with older children, but were only found among the premature babies. If no secondary infection intervened, then the cases as a whole responded rapidly, provided the treatment was adequate.

Case incidence. It will be obvious that owing to the impossibility of investigating all the cases that were admitted, it is equally impossible to give an accurate estimate of the incidence of a disease such as rickets. But by reference to the tables given it will be seen that of 2,000 admissions of children under six years old between January and September, 1939 , there were 81 diagnosed as rickets, either by x-ray examination or post mortem findings. In a series of 1000 consecutive admissions in August to November, 1940, when investigations were more complete, 100 cases were found to have beaded ribs. Of these 83 were x-rayed and 59 of them showed radiological evidence of rickets.

Treatment. It is apparent that the rickets with which we are principally dealing is due to lack of vitamin $\mathrm{D}$ and lack of mineral salts. The majority of cases responded well to treatment, e.g. table 1 . Admission No. 1543 on 26 June, 1939:

A Chinese male infant, aged eight months, had been fed from birth on sweetened condensed milk, 
with occasional breast feeds for the first month. For one week the infant had had fever and cough.

The Wassermann reactions of the mother and father were negative; a brother, aged three years, was healthy; a sister had died at the age of six months.

On admission, the infant was cyanosed, flabby and dyspnoeic; the knee jerks were sluggish and the heart rapid. Examination of the chest showed moist sounds. The infant's weight was $12 \mathrm{lb}$., temperature $101^{\circ} \mathrm{F}$., pulse ++ . The respiration rate was 60 . The ribs were beaded +++ and the joints enlarged. There was no craniotabes. X-ray diagnosis: Rickets ++ with 'periostitis' ++ . W.R. negative, and after provocative dose of arsenicals remained still negative.

The diagnosis of pneumonia, beri-beri and rickets was made.

TREATMENT. The infant was given nasal oxygen and intramuscular vitamin B1, 2000 units daily for three days, and atropine. The condition of the chest and heart improved rapidly. Further treatment consisted of adexolin minims 10 t.d.s., Meads mineral tablets, 1 t.d.s., and ultra-violet light (ten treatments).

Progress. 19th July, 1939. 'Well-marked improvement, (x-ray report).

9th August, 1939. 'Further satisfactory progress' (x-ray report).

The infant was discharged fit in two months.

NotE. The rapid progress could be seen in the $\mathrm{x}$-rays. The radiologist reported that the $\mathrm{x}$-ray appearances were those of syphilis, but as a clinician I was unable to agree. This child had been visited seven times by the Health visitor, but the threehourly feeds, the washing of the bottle, and the water in between feeds which was persistently recommended had done nothing to prevent either the beri-beri or the rickets.

It was noticed that the cases that were given calcium combined with other mineral salts seemed to recover more quickly than those that received calcium only.

A few cases were given large 'depot' doses of calciferol as recommended by some American authors, and, as far as our observation went, they also progressed favourably.

Among the premature babies we found that although we could not prevent rickets, yet with close attention to diet and regimen, the harmful secondary infections might be avoided. Anaemia in these babies was an obstinate symptom, sometimes needing transfusions.

Among congenital syphilitics it was found almost hopeless to treat either the rickets or the syphilis unless the babies were breast fed. It was possible to do a fair number of routine Kahn or Wassermann tests, both on the babies and on the parents, and it was very rare that clinical findings differed from serological, so that I cannot believe we were missing cases of congenital syphilis.

Cases that had convulsions often needed the most drastic treatment, and were often fatal in spite of it. Calcium had to be given in large doses and by every available route. Convulsions sometimes could only be controlled by frequent inhalations of chloroform. Lumbar puncture sometimes had to be performed three or four times a day and clear fluid under excessive pressure was removed on each occasion. In one child with a particularly large opening, the tense, bulging fontanelle looked like a small pyramid on the top of the head. Aperients and enemata were also used. Of the sedatives, chloral and bromide and sometimes luminal were given. Acidosis was also treated.

Prevention. In all paediatric subjects prevention is the most important aspect and rickets in this country is eminently preventible.

The first necessity is education-

(a) of the doctors, so that the disease receives some attention and adequate treatment;

(b) of the dressers and nurses and health visitors, so that they recognize the disease and can advise how it should be prevented;

(c) of the population, so that they learn how to provide the proper food and care and sunlight for the babies.

The other measures-improved housing and improved social conditions, so that mothers of young babies can stay at home and feed them instead of going out to work, will come with improved education.

I should like to record my gratitude to the sisters and nurses with whom I have worked, to my various House Physicians, particularly Dr. William Heng, M.B., D.C.H.; to the pathologists, particularly Dr. L. S. da Silva for studies of morbid anatomy and Dr. R. Sreenevasan for blood chemistry; to the radiologists for their patience with my cases and with my arguments; and, finally, to Mrs. MacCarthy and Mrs. Mackenzie who have done the typing, often under difficulties.

PosTSCRIPT. These figures and records were made between September, 1937, and February, 1941, during which time, apart from periods of leave, I was in charge of the children's wards at the General Hospital, Singapore, and Lecturer in Paediatrics at the College of Medicine. In early 1941 I went to the Unfederated State of Trengganu, in order to hold locum for the state medical officer, and to start welfare work. In December, 1941, we had to escape hurriedly through the jungle, carrying our own loads. The journey took ten days. The notes on rickets were at the bottom of my pack, but unfortunately not the histological slides. In Singapore I was in charge of the children's wards (then transferred to Tan Tok Seng Hospital) when we were forced to evacuate 120 children back to the General Hospital at twelve minutes' notice. I was permitted to visit the old quarters some weeks after the capitulation, and though the things had been looted, the notes on rickets were still lying on a shelf. They went with me into internment at Changi Prison, which afforded leisure to write them up. These observations are obviously very defective, but there has been no access to hospital records to complete them and little access to books of reference. For these and other defects, apologies are offered. 


\section{REFERENCES}

Kingsbury, A. N. and Fasal, P. (1940). Bull. Inst. M., Research, Fed. Malay States, 1, 1, and 2, 1.

Oliviero, C. J. (1941). 'Good health through feeding,' 5.
Park, E. A., and Eliot, M. M. (1933).' 'Diseases of infancy and childhood,' ed. Parsons, L. G., and Barling, S., 253. London.

Rosedale, J. L. (1934). Trans. 9th Congress Far East. Assoc. Trop. Med., 327.

\section{APPENDIX}

CHILDREN'S WARDS, GENERAL HOSPITAL, SINGAPORE, JANUARY TO SEPTEMBER, 1939

ANALYSIS OF 2000 CONSECUTIVE ADMISSIONS (children under 6 years)

Deaths-post mortem 228

No post mortem 530$\} \quad$. $\quad$. $\quad 758$

Not improved and transferred $\quad \ldots \quad$. . 198

$\begin{array}{lllllll}\text { Improved } & \ldots & \ldots & \ldots & \ldots & \ldots & 600\end{array}$

$\begin{array}{lllllll}\text { Cured .. } & \ldots & \ldots & . . & \ldots & \ldots & \\ \end{array}$

$\left.\begin{array}{l}\text { Still in hospital } \\ \text { Lodgers }\end{array}\right\} \quad \ldots \quad \ldots \quad$.. 156

$\begin{array}{lllll}\text { Records incomplete } & \cdots & \cdots & \cdots & \frac{156}{2000}\end{array}$

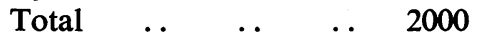

Cases with clinical evidence of rickets $\quad$. $\quad 118$

Rickets diagnosed by x-ray or post-mortem evidence $\begin{array}{llll}\text { Total cases of congenital syphilis } & \text {. } & \ldots & 19\end{array}$ $\begin{array}{llll}\text { Congenital syphilis plus rickets } & \ldots & \ldots & 4\end{array}$

Cases 304, 640, 1257 and 1347 were reported on by the radiologist who, at that time, believed that what he described as periostitis was invariably associated with congenital syphilis; therefore the diagnosis may be considered in doubt, and the cases should probably be classified among the ' rickets.'

Histories of feeding, etc., are often incomplete if the patients were admitted at night, or the relatives did not appear again, or could not be traced.

\section{Abbreviations used in tables.}

Race $-\mathrm{C}=$ Chinese, $\mathrm{I}=$ Indian, $\mathrm{M}=$ Malay.

N.I. $=$ Not improved and transferred.

P.M. $=$ Died and post mortem.

81 S.C.M. $=$ Sweetened condensed milk.

TABLE 1

INCIDENCE OF RICKETS AMONG 2000 CONSECUTIVE ADMISSIONS, JANUARY TO SEPTEMBER, 1939

(Rickets and some other conditions are described.)

\begin{tabular}{|c|c|c|c|c|c|c|}
\hline $\begin{array}{l}\text { Case } \\
\text { No. }\end{array}$ & $\left|\begin{array}{c}\text { Age } \\
\text { (months) }\end{array}\right|$ & Race & Sex & Result & Notes & Diagnosis \\
\hline 20 & 3 & C & $\mathbf{F}$ & Died & $\begin{array}{l}\text { Old case of rickets and anaemia-admitted } \\
\text { with pneumonia. Had been fed on sweet- } \\
\text { ened condensed milk. }\end{array}$ & $\begin{array}{l}\text { Rickets and pneu- } \\
\text { monia. }\end{array}$ \\
\hline 40 & 5 & C & $\mathbf{M}$ & Improved & $\begin{array}{l}\text { Fed on S.C.M. X-ray ' suggestive rickets.' } \\
\text { W.R. and Kahn negative. }\end{array}$ & Rickets. \\
\hline 41 & 2 & $\mathrm{C}$ & $\mathbf{M}$ & Improved & $\begin{array}{l}\text { Fed on S.C.M. X-ray 'suggestive of minor } \\
\text { rachitic changes.' W.R. and Kahn test } \\
\text { negative. }\end{array}$ & Rickets and anaemia. \\
\hline & 2 & C & $\mathbf{M}$ & P.M. & $\begin{array}{l}\text { Artificial feeding. } X \text {-ray 'slight but definite } \\
\text { rickets. }\end{array}$ & Rickets and enteritis. \\
\hline $\begin{array}{l}51 \\
57\end{array}$ & $\begin{array}{l}4 \\
2\end{array}$ & $\begin{array}{l}\mathrm{C} \\
\mathrm{C}\end{array}$ & $\begin{array}{l}\mathbf{M} \\
\mathbf{M}\end{array}$ & $\begin{array}{l}\text { Improved } \\
\text { Improved }\end{array}$ & $\begin{array}{l}\text { S.C.M. X-ray 'slight rachitic changes.' } \\
\text { S.C.M. X-ray 'definite but not marked } \\
\text { rickets.' Haemoglobin } 50 \text { per cent. }\end{array}$ & $\begin{array}{l}\text { Rickets. } \\
\text { Rickets and anaemia. }\end{array}$ \\
\hline 62 & 7 & C & $\mathbf{F}$ & P.M. & X-ray 'slight but definite rickets.' & $\begin{array}{l}\text { Rickets, beri-beri and } \\
\text { pneumonia. }\end{array}$ \\
\hline $\begin{array}{l}74 \\
76\end{array}$ & $\begin{array}{l}2 \\
2\end{array}$ & I & $\begin{array}{l}\mathbf{M} \\
\mathbf{M}\end{array}$ & $\begin{array}{l}\text { N.I. } \\
\text { Improved }\end{array}$ & $\begin{array}{l}\text { S.C.M. X-ray ' definite rickets.' } \\
\text { S.C.M. X-ray ' minor rachitic changes.' }\end{array}$ & $\begin{array}{l}\text { Rickets. } \\
\text { Rickets. }\end{array}$ \\
\hline 103 & 2 & $\mathrm{C}$ & $\mathbf{M}$ & P.M. & Ribs beaded, etc. & Rickets. \\
\hline 115 & 6 & $\mathbf{C}$ & $\mathbf{M}$ & Improved & Ribs beaded. & Malnutrition. \\
\hline 122 & 4 & C & $\mathbf{M}$ & P.M & $\begin{array}{l}\text { Ribs beaded. Head retraction and engorge- } \\
\text { ment of brain due to ? beri-beri, ? calcium } \\
\text { deficiency. }\end{array}$ & Meningismus. \\
\hline $\begin{array}{l}188 \\
202\end{array}$ & $\begin{array}{l}3 \\
7\end{array}$ & $\stackrel{\mathrm{C}}{\mathrm{C}}$ & $\begin{array}{l}\mathbf{M} \\
\mathbf{M}\end{array}$ & $\begin{array}{l}\text { Improved } \\
\text { Improved }\end{array}$ & $\begin{array}{l}\text { S.C.M. since birth. Beaded ribs. } \\
\text { S.C.M. Ribs beaded. X-ray negative. }\end{array}$ & $\begin{array}{l}\text { Malr. strition. } \\
\text { Malı't? ition. }\end{array}$ \\
\hline 219 & 6 & C & $\mathbf{M}$ & P.M. & $\begin{array}{l}\text { Breast fed } 3 \text { months, then S.C.M. Admitted } \\
\text { with severe convulsions, not controlled by } \\
\text { vitamin B or by calcium. W.R. negative. } \\
\text { X-ray 'rickets.' }\end{array}$ & Rickets. \\
\hline 304 & 3 & C & F & Improved & $\begin{array}{l}\text { Furunculosis. Beaded ribs. X-ray 'perios- } \\
\text { titis.' W.R. negative. }\end{array}$ & Furunculosis. \\
\hline $\begin{array}{l}326 \\
327\end{array}$ & 2 . & $\stackrel{\mathrm{C}}{\mathrm{C}}$ & $\begin{array}{l}\mathrm{F} \\
\mathbf{M}\end{array}$ & $\begin{array}{l}\text { Improved } \\
\text { Improved }\end{array}$ & $\begin{array}{l}\text { X-ray 'minor rickets.' } \\
\text { S.C.M. W.R. negative. X-ray 'suggestive } \\
\text { rickets.' }\end{array}$ & $\begin{array}{l}\text { Rickets. } \\
\text { Rickets and beri-beri }\end{array}$ \\
\hline
\end{tabular}


TABLE 1.-continued

\begin{tabular}{|c|c|c|c|c|c|c|}
\hline $\begin{array}{l}\text { Case } \\
\text { No. }\end{array}$ & $\begin{array}{c}\text { Age } \\
\text { (months) }\end{array}$ & Race & Sex & Result & Notes & Diagnosis \\
\hline $\begin{array}{l}339 \\
342\end{array}$ & $\begin{array}{l}3 \\
5\end{array}$ & $\begin{array}{l}\mathrm{C} \\
\mathrm{C}\end{array}$ & $\begin{array}{l}\mathbf{F} \\
\mathbf{M}\end{array}$ & $\begin{array}{l}\text { Improved } \\
\text { N.I. }\end{array}$ & $\begin{array}{l}\text { S.C.M. X-ray 'definite rickets.' } \\
\text { S.C.M. Beaded ribs. No x-ray. }\end{array}$ & $\begin{array}{l}\text { Rickets and beri-beri. } \\
\text { Malnutrition and } \\
\text { diphtheria. }\end{array}$ \\
\hline 354 & $\begin{array}{l}4 \\
2\end{array}$ & $\stackrel{\mathrm{C}}{\mathrm{C}}$ & $\mathbf{M}$ & $\begin{array}{l}\text { Improved } \\
\text { P.M. }\end{array}$ & Congenital syphilis-Kahn test positive. & $\begin{array}{l}\text { Congenital syphilis. } \\
\text { Rickets and enteritis. }\end{array}$ \\
\hline $\begin{array}{l}386 \\
394\end{array}$ & $\begin{array}{l}6 \\
4\end{array}$ & $\begin{array}{l}\mathrm{C} \\
\mathbf{C}\end{array}$ & $\begin{array}{l}\mathrm{F} \\
\mathrm{M}\end{array}$ & $\begin{array}{l}\text { Improved } \\
\text { Improved }\end{array}$ & $\begin{array}{l}\text { S.C.M. X-ray ' minor rickets.' } \\
\text { S.C.M. (adopted child). X-ray ' definite } \\
\text { rickets.' }\end{array}$ & $\begin{array}{l}\text { Rickets. } \\
\text { Rickets. }\end{array}$ \\
\hline 427 & 2 & $\mathrm{C}$ & $\mathbf{M}$ & Improved & $\begin{array}{l}\text { Breast fed. Anaemic. Beaded ribs. X-ray } \\
\text { negative. }\end{array}$ & Anaemia. \\
\hline 430 & 10 & $\mathrm{C}$ & $\mathbf{F}$ & Improved & $\begin{array}{l}\text { Mixed feeding. S.C.M. and breast milk. } \\
\text { X-ray "rickets present." }\end{array}$ & Rickets. \\
\hline 439 & 1 & C & $\mathbf{M}$ & Improved & $\begin{array}{l}\text { Breast fed. Ribs beaded. Convulsions. X- } \\
\text { ray negative. }\end{array}$ & Convulsions. \\
\hline $\begin{array}{l}460 \\
463 \\
478\end{array}$ & $\begin{array}{l}2 \\
4 \\
4\end{array}$ & $\begin{array}{l}\mathrm{C} \\
\mathrm{C} \\
\mathrm{C}\end{array}$ & $\begin{array}{l}\text { M } \\
F \\
F\end{array}$ & $\begin{array}{l}\text { Died } \\
\text { Improved } \\
\text { Improved }\end{array}$ & $\begin{array}{l}\text { S.C.M. X-ray positive. } \\
\text { S.C.M. X-ray 'suggestive rickets.' }\end{array}$ & $\begin{array}{l}\text { Congenital syphilis. } \\
\text { Rickets. } \\
\text { Malnutrition and }\end{array}$ \\
\hline $\begin{array}{l}493 \\
500\end{array}$ & $\begin{array}{l}2 \\
3\end{array}$ & $\begin{array}{l}\mathrm{C} \\
\mathrm{C}\end{array}$ & $\begin{array}{l}\mathrm{F} \\
\mathrm{M}\end{array}$ & $\begin{array}{l}\text { Improved } \\
\text { Improved }\end{array}$ & $\begin{array}{l}\text { Mixed feeding. X-ray 'definite rickets.' } \\
\text { Mongol. W. W. negative. X-ray 'rickets } \\
\text { present.' }\end{array}$ & $\begin{array}{l}\text { rickets. } \\
\text { Rickets. } \\
\text { Mongolism and } \\
\text { rickets. }\end{array}$ \\
\hline 512 & 3 & C & $\mathbf{M}$ & Improved & $\begin{array}{l}\text { S.C.M. W.R. negative. X-ray 'marked } \\
\text { rickets.' }\end{array}$ & Rickets. \\
\hline $\begin{array}{l}515 \\
522 \\
533 \\
565\end{array}$ & $\begin{array}{r}13 \\
7 \\
3 \\
7\end{array}$ & $\begin{array}{l}\mathrm{C} \\
\mathrm{C} \\
\mathrm{C} \\
\mathrm{C}\end{array}$ & $\begin{array}{l}\mathbf{F} \\
\mathbf{M} \\
\mathbf{F} \\
\mathbf{M}\end{array}$ & $\begin{array}{l}\text { Cured } \\
\text { Cured } \\
\text { N.I. } \\
\text { P.M. }\end{array}$ & $\begin{array}{l}\text { S.C.M. X-ray ' healing rickets.' } \\
\text { Beaded ribs. X-ray negative. } \\
\text { X-ray 'slight periostitis.' W.R. positive. } \\
\text { Old case readmitted with pneumonia. }\end{array}$ & $\begin{array}{l}\text { Pyelitis and rickets. } \\
\text { Pyelitis. } \\
\text { Congenital syphilis. } \\
\text { Rickets and pneu- } \\
\text { monia. }\end{array}$ \\
\hline $\begin{array}{l}599 \\
607\end{array}$ & $\begin{array}{l}3 \\
5\end{array}$ & $\stackrel{\mathrm{C}}{\mathrm{C}}$ & $\begin{array}{l}\mathrm{M} \\
\mathrm{F}\end{array}$ & $\begin{array}{l}\text { Died } \\
\text { Improved }\end{array}$ & Old case readmitted. & $\begin{array}{l}\text { Congenital syphilis. } \\
\text { Rickets and bron- } \\
\text { chitis. }\end{array}$ \\
\hline 640 & 3 & $\mathbf{M}$ & $\mathbf{F}$ & Improved & $\begin{array}{l}\text { S.C.M. Beaded ribs. X-ray 'periostitis.' } \\
\text { W.R. negative. }\end{array}$ & $\begin{array}{l}\text { Enteritis and 'perios- } \\
\text { titis.' }\end{array}$ \\
\hline 644 & 8 & $\mathrm{C}$ & F & Died & $\begin{array}{l}\text { Well-marked beading, etc. Bronchitis and } \\
\text { beri-beri. }\end{array}$ & $\begin{array}{l}\text { Rickets and bron- } \\
\text { chitis. }\end{array}$ \\
\hline $\begin{array}{l}673 \\
686\end{array}$ & $\begin{array}{r}3 \\
10\end{array}$ & $\stackrel{\mathrm{C}}{\mathrm{C}}$ & $\begin{array}{l}\mathbf{M} \\
\mathbf{M}\end{array}$ & $\begin{array}{l}\text { N.I. } \\
\text { N.I. }\end{array}$ & $\begin{array}{l}\text { S.C.M. X-ray ' definite rickets.' } \\
\text { X-ray 'doubtful syphilis.' W.R. negative. }\end{array}$ & $\begin{array}{l}\text { Rickets and enteritis. } \\
\text { Epiphysitis and en- } \\
\text { teritis. }\end{array}$ \\
\hline $\begin{array}{l}735 \\
738 \\
777\end{array}$ & $\begin{array}{l}1 \\
3 \\
5\end{array}$ & $\begin{array}{l}\text { C } \\
\text { I } \\
\text { C }\end{array}$ & $\begin{array}{l}\mathbf{M} \\
\mathrm{F} \\
\mathbf{M}\end{array}$ & $\begin{array}{l}\text { Improved } \\
\text { Improved } \\
\text { Cured }\end{array}$ & $\begin{array}{l}\text { Beaded ribs. X-ray negative. } \\
\text { S.C.M. Beaded ribs. X-ray negative. } \\
\text { Old case of rickets. Beri-beri and pneumonia. }\end{array}$ & $\begin{array}{l}\text { Pneumonia. } \\
\text { Malnutrition. } \\
\text { Beri-beri and pneu- } \\
\text { monia. }\end{array}$ \\
\hline 824 & 4 & $\mathrm{C}$ & $\mathbf{M}$ & Improved & S.C.M. X-ray 'definite rickets.' & $\begin{array}{l}\text { monia. } \\
\text { Rickets and convul- } \\
\text { sions. }\end{array}$ \\
\hline 876 & 2 & I & F & Died & $\begin{array}{l}\text { S.C.M. 'Born with deformities.' X-ray } \\
\text { 'marked rickets.' }\end{array}$ & Rickets. \\
\hline 887 & 9 & $\mathrm{C}$ & $\mathbf{M}$ & Improved & Beaded ribs. X-ray negative. & $\begin{array}{l}\text { Whooping-cough and } \\
\text { enteritis. }\end{array}$ \\
\hline 892 & 17 & I & $\mathbf{F}$ & Improved & X-ray ' marked rickets.' & $\begin{array}{l}\text { Rickets, ascariasis } \\
\text { and pneumonia. }\end{array}$ \\
\hline 897 & 10 & $\mathrm{C}$ & $\mathbf{F}$ & N.I. & $\begin{array}{l}\text { S.C.M. X-ray 'suggestive rickets.' Beaded } \\
\text { ribs. }\end{array}$ & Rickets and enteritis. \\
\hline 918 & 6 & $\mathrm{C}$ & $\mathbf{F}$ & Improved & $\begin{array}{l}\text { S.C.M. } \\
\text { rickets.' }\end{array}$ Beaded ribs. X-ray 'marked & Rickets. \\
\hline 936 & 2 & $\mathrm{C}$ & $\mathbf{M}$ & Improved & $\begin{array}{l}\text { Breast-fed. Some beading. W.R. }+++ \text {. } \\
\text { X-ray "rickets and periostitis.' }\end{array}$ & $\begin{array}{l}\text { Congenital syphilis } \\
\text { and rickets. }\end{array}$ \\
\hline 964 & 8 & $\mathrm{C}$ & $\mathbf{F}$ & Improved & $\begin{array}{l}\text { S.C.M. Beading of ribs }++ \text { X-ray nega- } \\
\text { tive. }\end{array}$ & Enteritis. \\
\hline 965 & 4 & C & $\mathbf{M}$ & Improved & 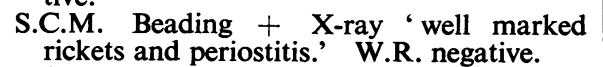 & Rickets and enteritis. \\
\hline $\begin{array}{l}975 \\
991\end{array}$ & 2 & $\stackrel{\mathbf{C}}{\mathbf{C}}$ & $\begin{array}{l}\mathbf{F} \\
\mathbf{M}\end{array}$ & $\begin{array}{l}\text { Improved } \\
\text { Died }\end{array}$ & $\begin{array}{l}\text { S.C.M. Beaded ribs. X-ray 'minor rickets.' } \\
\text { S.C.M. Syphilis. Kahn test }+++ \text { X-ray } \\
\text { periostitis and defective occification.' }\end{array}$ & $\begin{array}{l}\text { Rickets and enteritis. } \\
\text { Congenital syphilis. }\end{array}$ \\
\hline 1002 & 7 & $\mathbf{C}$ & $\mathbf{F}$ & Died & $\begin{array}{l}\text { Enteritis, etc. Beaded ribs. X-ray 'rickets, } \\
\text { marked.' }\end{array}$ & Rickets. \\
\hline 1004 & 2 & C & $\mathbf{M}$ & N.I. & $\begin{array}{l}\text { Beaded ribs. Anaemia }+. \text { X-ray ' marked } \\
\text { rickets.' }\end{array}$ & Rickets and anaemia. \\
\hline 1007 & 24 & $\mathrm{C}$ & $\mathbf{M}$ & Died & $\begin{array}{l}\text { S.C.M. Ribs beaded. X-ray ' bones poorly } \\
\text { calcified.' }\end{array}$ & Malnutrition. \\
\hline 1010 & 36 & C & $\mathbf{M}$ & Improved & Beaded ribs. X-ray 'no rickets.' & $\begin{array}{l}\text { Malnutrition and } \\
\text { pneumonia. }\end{array}$ \\
\hline 1012 & 12 & $\mathrm{C}$ & $\mathbf{M}$ & N.I. & $\begin{array}{l}\text { S.C.M. Anaemic. Beaded ribs. X-ray } \\
\text { early rickets.' }\end{array}$ & Rickets and anaemia. \\
\hline
\end{tabular}


TABLE 1.-continued

\begin{tabular}{|c|c|c|c|c|c|c|}
\hline $\begin{array}{l}\text { Case } \\
\text { No. }\end{array}$ & $\underset{\text { Age }}{\text { (months) }}$ & Race & Sex & Result & Notes & Diagnosis \\
\hline 1022 & 3 & C & $\mathbf{F}$ & Died & Old case of rickets. Convulsions ++ . & Rickets and convul- \\
\hline 1033 & 4 & $\mathrm{C}$ & $F$ & P.M. & $\begin{array}{l}\text { S.C.M. X-ray 'rickets present.' Cerebral } \\
\text { irritation. }\end{array}$ & Malaria and rickets. \\
\hline 1041 & 2 & $\mathrm{C}$ & $F$ & Improved & S.C.M. X-ray ' minor rachitic changes.' & $\begin{array}{l}\text { Rickets and convul- } \\
\text { sions. }\end{array}$ \\
\hline 1046 & 7 & C & $\mathbf{M}$ & Improved & Breast fed. X-ray ' healing rickets.' & Rickets and convul- \\
\hline 1053 & 12 & $\mathrm{C}$ & F & N.I. & Beaded ribs. Bronchitis. X-ray negative. & $\begin{array}{l}\text { Beri-beri and bron- } \\
\text { chitis. }\end{array}$ \\
\hline 1054 & 7 & C & $\mathbf{M}$ & N.I. & $\begin{array}{l}\text { S.C.M. Beaded ribs. X-ray 'periostitis } \\
\text { present }- \text { no rickets.' }\end{array}$ & $\begin{array}{c}\text { Furunculosis } \\
\text { 'periostitis.' and }\end{array}$ \\
\hline 1061 & 24 & $\mathrm{C}$ & $\mathbf{F}$ & Improved & $\begin{array}{l}\text { S.C.M. Appearance rickety. Weight } 13 \frac{1}{2} \mathrm{lb} \text {. } \\
\text { at } 2 \text { years. X-ray negative for rickets. }\end{array}$ & $\begin{array}{c}\text { Malnutrition } \\
\text { bronchitis. }\end{array}$ \\
\hline 1063 & 6 & $\mathrm{C}$ & $\mathbf{F}$ & Died & $\begin{array}{l}\text { S.C.M. Beaded ribs. X-ray, 'negative for } \\
\text { rickets. Periostitis present.' }\end{array}$ & Malnutrition. \\
\hline $\begin{array}{l}1077 \\
1086\end{array}$ & $\begin{array}{l}5 \\
8\end{array}$ & $\stackrel{\text { C }}{\mathbf{C}}$ & $\begin{array}{l}\mathbf{F} \\
\mathbf{M}\end{array}$ & $\begin{array}{l}\text { Improved } \\
\text { N.I. }\end{array}$ & S.C.M. Ribs beaded. X-ray negative. & $\begin{array}{l}\text { Pyelo-nephritis. } \\
\text { Mongolism } \\
\text { rickets. }\end{array}$ and \\
\hline 1090 & 6 & $\mathrm{C}$ & $\mathbf{M}$ & Improved & $\begin{array}{l}\text { S.C.M. Enteritis. Beaded ribs. Not x- } \\
\text { rayed. }\end{array}$ & Enteritis. \\
\hline 1108 & 5 & C & $\mathbf{M}$ & P.M. & $\begin{array}{l}\text { Beaded ribs. X-ray 'rickets marked and } \\
\text { symmetrical periostitis.' W.R. negative. }\end{array}$ & Rickets. \\
\hline 1137 & 7 & $\mathbf{C}$ & $\mathbf{M}$ & Cured & $\begin{array}{l}\text { Mixed feeding. Beaded ribs. X-ray nega- } \\
\text { tive. }\end{array}$ & Enteritis. \\
\hline $\begin{array}{l}1142 \\
1170\end{array}$ & $\begin{array}{l}1 \\
2\end{array}$ & $\begin{array}{l}\mathrm{C} \\
\mathrm{C}\end{array}$ & $\begin{array}{l}\mathrm{F} \\
\mathbf{M}\end{array}$ & $\begin{array}{l}\text { Died } \\
\text { Died }\end{array}$ & $\begin{array}{l}\text { S.C.M.? Beaded ribs. X-ray 'minor rickets.' } \\
\text { S.C.M. X-ray 'periostitis and cuffing.' } \\
\text { W.R. and Kahn test negative. }\end{array}$ & $\begin{array}{l}\text { Rickets and enteritis. } \\
\text { Rickets. }\end{array}$ \\
\hline 1174 & 1 & $\mathrm{C}$ & $\mathbf{M}$ & Died & $\begin{array}{l}\text { S.C.M. Beaded ribs, etc. X-ray 'minor } \\
\text { rickets and periostitis.' }\end{array}$ & Rickets and enteritis. \\
\hline $\begin{array}{l}1177 \\
1178\end{array}$ & $\begin{array}{l}3 \\
4\end{array}$ & $\stackrel{\mathrm{C}}{\mathrm{C}}$ & $\begin{array}{l}\mathbf{M} \\
\mathbf{M}\end{array}$ & $\begin{array}{l}\text { Improved } \\
\text { Improved }\end{array}$ & $\begin{array}{l}\text { S.C.M. Beaded ribs. X-ray negative. } \\
\text { S.C.M. Beaded ribs. X-ray 'minor rickets } \\
\text { and periostitis.' }\end{array}$ & $\begin{array}{l}\text { Beri-beri. } \\
\text { Rickets and beri-beri. }\end{array}$ \\
\hline 1190 & 6 & $\mathrm{C}$ & $\mathrm{F}$ & Improved & $\begin{array}{l}\text { S.C.M. X-ray ' flaring and cuffing and } \\
\text { erosion of cortex.' Kahn test negative. }\end{array}$ & $\begin{array}{l}\text { Rickets and bron- } \\
\text { chitis. }\end{array}$ \\
\hline $\begin{array}{l}1198 \\
1201\end{array}$ & $\begin{array}{r}24 \\
4\end{array}$ & $\begin{array}{l}\text { C } \\
\text { I }\end{array}$ & $\begin{array}{l}\mathrm{F} \\
\mathrm{M}\end{array}$ & $\begin{array}{l}\text { Improved } \\
\text { Cured }\end{array}$ & $\begin{array}{l}\text { Syphilitic. W.R. }+++ \\
\text { Breast fed. Beaded ribs. X-ray 'minor } \\
\text { rickets.' }\end{array}$ & $\begin{array}{l}\text { Congenital syphilis. } \\
\text { Rickets. }\end{array}$ \\
\hline 1214 & 6 & $\mathrm{C}$ & $\mathbf{M}$ & Improved & $\begin{array}{l}\text { S.C.M. } \\
\text { cent. }\end{array}$ & Rickets and anaemia. \\
\hline 1222 & 8 & I & $\mathbf{M}$ & Improved & $\begin{array}{l}\text { Breast fed. X-ray ' gross rickets and sym- } \\
\text { metrical periostitis.' W.R. negative. Both } \\
\text { parents W.R. negative. }\end{array}$ & $\begin{array}{l}\text { Rickets and convul- } \\
\text { sions. }\end{array}$ \\
\hline $\begin{array}{l}1229 \\
1257 \\
1288\end{array}$ & $\begin{array}{l}3 \\
3 \\
4\end{array}$ & $\begin{array}{l}\mathrm{C} \\
\mathrm{C} \\
\mathrm{C}\end{array}$ & $\begin{array}{l}\mathbf{F} \\
\mathbf{F} \\
\mathbf{M}\end{array}$ & $\begin{array}{l}\text { Improved } \\
\text { Died } \\
\text { Improved }\end{array}$ & $\begin{array}{l}\text { S.C.M. Beaded ribs. X-ray negative. } \\
\text { Beaded ribs. X-ray ' rickets and syphilis.' } \\
\text { S.C.M. Beaded ribs }++\quad \text { X-ray negative. }\end{array}$ & $\begin{array}{l}\text { Beri-beri. } \\
\text { Rickets and enteritis. } \\
\text { Malnutrition. }\end{array}$ \\
\hline & 4 & $\mathrm{C}$ & $\mathbf{M}$ & & Beaded ribs. X-ray 'rickets present.' & $\begin{array}{l}\text { Rickets and pneu- } \\
\text { monia. }\end{array}$ \\
\hline 1297 & 1 & $\stackrel{\text { C }}{\mathrm{C}}$ & $\mathbf{M}$ & $\begin{array}{l}\text { Died } \\
\text { Died }\end{array}$ & $\begin{array}{l}\text { Beaded ribs }++ \text { S.C.M. } \\
\text { Congenital syphilis and beaded ribs. }\end{array}$ & $\begin{array}{l}\text { Beri-beri and rickets. } \\
\text { Congenital syphilis. }\end{array}$ \\
\hline & 8 & C & $\mathbf{M}$ & Innomed & $\begin{array}{l}\text { Emaciated. Beaded ribs. X-ray 'suggestive } \\
\text { rickets.' Kahn test negative. }\end{array}$ & Di \\
\hline 1347 & 8 & $\mathrm{C}$ & $\mathbf{M}$ & Improved & $\begin{array}{l}\text { S.C.M. Beaded, ribs, etc. X-ray ' rickets } \\
\text { and syphilis. W.R. negative. Both } \\
\text { parents W.R. negative. }\end{array}$ & Rickets and beri-beri. \\
\hline 1350 & 8 & $\mathrm{C}$ & F & Improved & $\begin{array}{l}\text { X-ray 'density of metaphysis.' Haemor- } \\
\text { rhages from gums, etc. }\end{array}$ & Scurvy. \\
\hline 1370 & 9 & C & $\mathbf{F}$ & Died & $\begin{array}{l}\text { Emaciated }++ \text { Ulcers }++ \text { Beaded ribs } \\
++ \text { X-ray for rickets negative. }\end{array}$ & Malnutrition. \\
\hline 1393 & $\begin{array}{l}9 \\
9\end{array}$ & $\stackrel{\mathrm{C}}{\mathrm{C}}$ & $\mathbf{F}$ & $\begin{array}{l}\text { Died } \\
\text { Improved }\end{array}$ & $\begin{array}{l}\text { Convulsions. Beaded ribs }++ \\
\text { Old case re-admitted. }\end{array}$ & $\begin{array}{l}\text { Rickets. } \\
\text { Rickets and ber-beri. }\end{array}$ \\
\hline 1420 & 8 & C & $\mathbf{F}$ & Died & $\begin{array}{l}\text { S.C.M. Beaded ribs. Syphilitic facies. } \\
\text { X-ray "periostitis.' Kahn test }+ \text { Both } \\
\text { parents Kahn test }+\end{array}$ & Congenital syphilis. \\
\hline 1460 & $\frac{3}{4}$ & $\mathbf{M}$ & $\mathbf{F}$ & N.I. & Beaded ribs. X-ray negative. & $\begin{array}{l}\text { Pneumonia and opth- } \\
\text { almia. }\end{array}$ \\
\hline 1998 & 2 & C & $\mathbf{M}$ & Died & Beaded ribs. Emaciated. & $\begin{array}{l}\text { Malnutrition. Cellu- } \\
\text { litis. }\end{array}$ \\
\hline 1543 & 8 & C & $\mathbf{M}$ & Improved & $\begin{array}{l}\text { Beaded ribs. X-ray 'rickets and periostitis.' } \\
\text { Kahn test negative. }\end{array}$ & Rickets and beri-beri. \\
\hline 1591 & $1 \frac{1}{2}$ & $\mathrm{C}$ & $\mathbf{M}$ & Improved & $\begin{array}{l}\text { Breast fed. Beaded ribs. X-ray 'slight } \\
\text { flaring of ulna.' }\end{array}$ & Beri-beri and rickets. \\
\hline
\end{tabular}


TABLE 1.-continued

\begin{tabular}{|c|c|c|c|c|c|c|}
\hline $\begin{array}{l}\text { Case } \\
\text { No. }\end{array}$ & $\begin{array}{c}\text { Age } \\
\text { (months) }\end{array}$ & Race & Sex & Result & Notes & Diagnosis \\
\hline 1600 & 1 & $\mathrm{C}$ & F & Died & $\begin{array}{l}\text { S.C.M. Anaemia, fits, enteritis. X-ray } \\
\text { 'bands of increased density at epiphyses. } \\
\text { Slight flaring of metaphyseal ends. No. } \\
\text { periostitis.' }\end{array}$ & Rickets. \\
\hline $\begin{array}{l}1601 \\
1616\end{array}$ & $3^{\frac{1}{4}}$ & $\stackrel{\text { C }}{\mathbf{C}}$ & $\begin{array}{l}\mathbf{M} \\
\mathbf{M}\end{array}$ & $\begin{array}{l}\text { Died } \\
\text { P.M. }\end{array}$ & S.C.M., X-ray 'periostitis and flaring of & $\begin{array}{l}\text { Congenital syphilis. } \\
\text { Rickets. }\end{array}$ \\
\hline 1625 & $1 \frac{1}{2}$ & C & F & Died & $\begin{array}{l}\text { Kahn test negative. } \\
\text { S.C.M. Beri-beri. Beaded ribs. X-ray } \\
\text { slight flaring of ulna.' }\end{array}$ & Beri-beri and rickets. \\
\hline 1666 & 6 & C & $\mathbf{M}$ & Improved & $\begin{array}{l}\text { Beaded ribs. Convulsions. X-ray 'rickets } \\
\text { present.' }\end{array}$ & $\begin{array}{l}\text { Rickets and convul- } \\
\text { sions. }\end{array}$ \\
\hline 1667 & 3 & C & M & Improved & $\begin{array}{l}\text { Beaded ribs. Convulsions. X-ray ' marked } \\
\text { rickets.' }\end{array}$ & $\begin{array}{l}\text { Rickets and convul- } \\
\text { sions. }\end{array}$ \\
\hline 1673 & 9 & $\mathrm{C}$ & $\mathbf{M}$ & Died & S.C.M. Beaded ribs. & $\begin{array}{l}\text { Rickets and pneu- } \\
\text { monia. }\end{array}$ \\
\hline $\begin{array}{l}1677 \\
1678\end{array}$ & $\begin{array}{l}2 \\
2\end{array}$ & $\begin{array}{l}\mathrm{C} \\
\mathrm{C}\end{array}$ & $\begin{array}{l}\mathrm{F} \\
\mathrm{F}\end{array}$ & $\begin{array}{l}\text { Improved } \\
\text { Died }\end{array}$ & $\begin{array}{l}\text { S.C.M. Blind. X-ray ' rickets and perios- } \\
\text { titis. }\end{array}$ & $\begin{array}{l}\text { Congenital syphilis. } \\
\text { Rickets and kerato- } \\
\text { malacia. }\end{array}$ \\
\hline 1693 & 7 & C & $\mathrm{F}$ & Died & $\begin{array}{l}\text { X-ray ' rickets and periostitis.' W.R. nega- } \\
\text { tive. }\end{array}$ & Rickets. \\
\hline 1698 & 16 & C & $\mathbf{M}$ & Improved & $\begin{array}{l}\text { Beaded ribs and laxity of ligaments. X-ray } \\
\text { negative. }\end{array}$ & Malnutrition. \\
\hline 1707 & 6 & $\mathrm{C}$ & F & Died & $\begin{array}{l}\text { S.C.M. Congenital heart. X-ray 'marked } \\
\text { rickets.' }\end{array}$ & $\begin{array}{c}\text { Rickets and con. } \\
\text { heart. }\end{array}$ \\
\hline $\begin{array}{l}1744 \\
1746\end{array}$ & $\begin{array}{l}2 \\
1 \frac{1}{2}\end{array}$ & $\stackrel{\mathrm{C}}{\mathrm{C}}$ & $\begin{array}{l}\mathbf{F} \\
\mathbf{M}\end{array}$ & $\begin{array}{l}\text { N.I. } \\
\text { P.M. }\end{array}$ & $\begin{array}{l}\text { Kahn test negative. W. R. }+ \\
\text { S.C.M. Convulsions. Kahn test negative. } \\
\text { X-ray 'rickets present.' }\end{array}$ & $\begin{array}{l}\text { Congenital syphilis. } \\
\text { Rickets and pneu- } \\
\text { monia. }\end{array}$ \\
\hline 1752 & 2 & $\mathrm{C}$ & $\mathbf{F}$ & N.I. & $\begin{array}{l}\text { S.C.M. Beaded ribs. Kahn test negative. } \\
\text { X-ray 'dense line of arrested growth.' }\end{array}$ & Malnutrition. \\
\hline 1760 & 6 & C & $\mathrm{F}$ & Cured & $\begin{array}{l}\text { S.C.M. Beaded ribs. X-ray 'dense line of } \\
\text { arrested growth.' }\end{array}$ & $\begin{array}{l}\text { Beri-beri and pneu- } \\
\text { monia. }\end{array}$ \\
\hline $\begin{array}{l}1769 \\
1775\end{array}$ & $\begin{array}{l}2 \\
6\end{array}$ & I & $\begin{array}{l}\mathrm{F} \\
\mathrm{M}\end{array}$ & $\begin{array}{l}\text { Improved } \\
\text { Died }\end{array}$ & $\begin{array}{l}\text { Syphilitic. Beri-beri. } \\
\text { S.C.M. Beaded ribs. X-ray ' suggestion of } \\
\text { periostitis and flaring.' }\end{array}$ & $\begin{array}{l}\text { Congenital syphilis. } \\
\text { Rickets. }\end{array}$ \\
\hline 1832 & 12 & C & $\mathbf{M}$ & & $\begin{array}{l}\text { Beaded ribs. Anaemia. X-ray 'rickets } \\
\text { present.' }\end{array}$ & Rickets and anaemia. \\
\hline 1843 & 5 & C & $\mathbf{M}$ & N.I. & $\begin{array}{l}\text { Syphilitic. X-ray 'periostitis.' W.R. doubt- } \\
\text { ful + }\end{array}$ & Congenital syphilis. \\
\hline $\begin{array}{l}1852 \\
1859 \\
1883 \\
1942\end{array}$ & $\begin{array}{l}2 \\
3 \\
6\end{array}$ & $\begin{array}{l}\text { I } \\
\text { C } \\
\text { C } \\
\text { C }\end{array}$ & $\begin{array}{l}\text { M } \\
\text { F } \\
\text { M } \\
\text { F }\end{array}$ & $\begin{array}{l}\text { N.I. } \\
\text { Improved } \\
\text { Died } \\
\text { Died }\end{array}$ & $\begin{array}{l}\text { W.R. }+ \\
\text { Beaded ribs, etc. X-ray negative. } \\
\text { W.R. }+ \text { Kahn test }+++ \\
\text { Beaded ribs. W.R. positive. X-ray 'posi- } \\
\text { tive for syphilis and rickets.' }\end{array}$ & $\begin{array}{l}\text { Congenital syphilis. } \\
\text { Malnutrition. } \\
\text { Congenital syphilis. } \\
\text { Congenital syphilis } \\
\text { and rickets. }\end{array}$ \\
\hline $\begin{array}{l}1943 \\
1975\end{array}$ & $\begin{array}{l}4 \\
6\end{array}$ & $\begin{array}{l}\mathrm{C} \\
\mathrm{C}\end{array}$ & $\begin{array}{l}\mathrm{M} \\
\mathrm{F}\end{array}$ & $\begin{array}{l}\text { N.I. } \\
\text { N.I. }\end{array}$ & $\begin{array}{l}\text { Beaded ribs, etc. X-ray 'rickets present.' } \\
\text { Jaundice. Beaded ribs. W.R. negative. X- } \\
\text { rav 'increased density of bone.' }\end{array}$ & $\begin{array}{l}\text { Rickets. } \\
\text { Rickets and enteritis. }\end{array}$ \\
\hline $\begin{array}{l}1988 \\
1992\end{array}$ & $\begin{array}{l}4 \\
3\end{array}$ & $\begin{array}{l}\mathrm{C} \\
\mathrm{C}\end{array}$ & $\begin{array}{l}\mathbf{M} \\
\mathbf{M}\end{array}$ & $\begin{array}{l}\text { Died } \\
\text { Died }\end{array}$ & $\begin{array}{l}\text { S.C.M. X-ray ' slight rickets, etc.' } \\
\text { S.C.M. Kahn test }+++ \text { X-ray ' rickets } \\
\text { fairly well marked.' }\end{array}$ & $\begin{array}{l}\text { Rickets and enteritis. } \\
\text { Congenital syphilis } \\
\text { and rickets. }\end{array}$ \\
\hline 1999 & 5 & $\mathrm{C}$ & $\mathbf{M}$ & Died & S.C.M. X-ray 'well-marked rickets.' & $\begin{array}{l}\text { Rickets and pneu- } \\
\text { monia. }\end{array}$ \\
\hline
\end{tabular}




\section{Illustrative case reports}

Case 1. (To show radiological appearance compared with histological report.)

History. A Chinese male infant, aged three months, was admitted on August 16, 1939, on account of recurrent convulsions. The patient was a twin (the other twin having died at three weeks of age) and had been fed on Alpine sweetened condensed milk.

FAMILY HISTORY. Both father and mother were alive and healthy; in both cases the Wassermann reaction was negative and there was no history of venereal disease. The mother had had one mis-

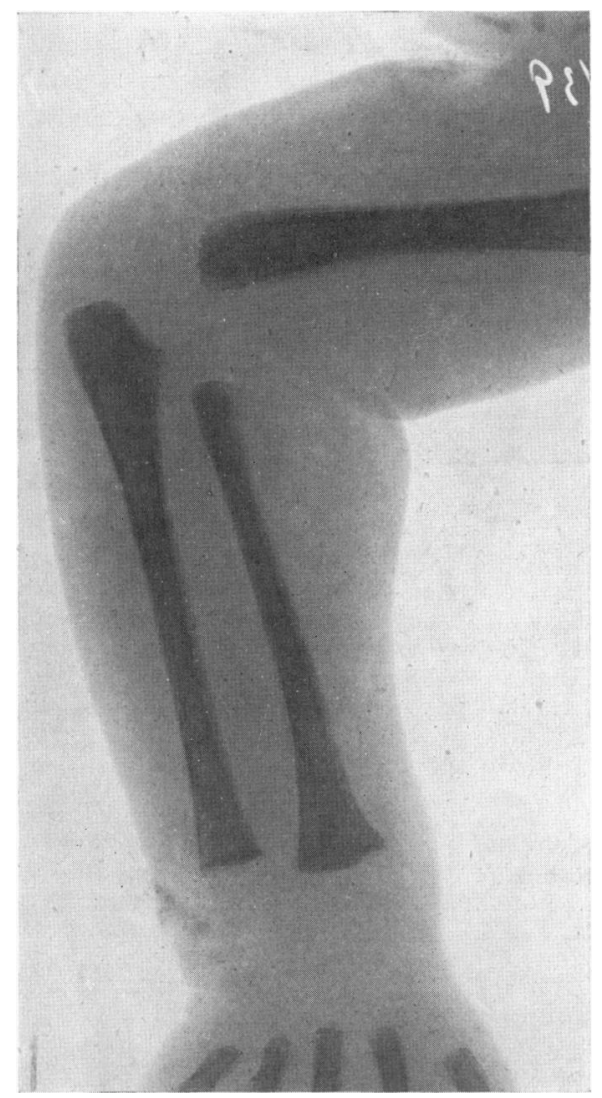

FIg. 1.-Case 1. 'Periostitis' and slight flaring of ulnar metaphysis. carriage at five months, two years previously. This was the second pregnancy.

EXAMINATION ON ADMISSION. The infant was having recurrent convulsions. The weight was $6 \mathrm{lb} .14 \mathrm{oz}$., the temperature $98^{\circ} \mathrm{F}$., the respiration rate 40 , and the pulse rate 130 per minute. The knee jerks were absent. The Wassermann reaction was negative (also after provocative injection).

RADIOLOGICAL REPORT. 'Periostitis' and slight flaring of ulnar metaphysis.

Progress. The infant was given vitamin B, 2000 units daily for three days, Adexolin minims 5 t.d.s., and Mead's mineral tablets 1 t.d.s. The general condition improved and the convulsions ceased, but after two weeks the infant developed pneumonia and enteritis and died.

POST-MORTEM (HISTOLOGICAL) REPORT. The rib shows well-marked widening of the zone of cartilage columns, with irregularity and distortion of the columns. Vascularity is marked. Osteoid substance is abundant. The knee shows slight irregularity of the cartilage columns. In the wrist, irregularity and distortion of the cartilage columns are present with increased vascularity, but are not as well marked as in the ribs. The osteoid substance is increased.

DiAGNOSIS. Rickets and beri-beri; terminal enteritis and pneumonia.

Case 2. (To show rapid recovery with treatment.)

History. A Chinese male infant, aged eight months, was admitted June 26 to August 10, 1939. The infant had been fed on sweetened condensed milk from birth; for one week there had been fever and cough.

FAMILY HISTORY. Both parents alive and well, and in both cases the Wassermann reaction was negative. One older child, aged three years, was healthy; a second child died, aged six months; the patient was the third child.

ExAMINATION ON ADMISSION. The infant weighed $12 \mathrm{lb}$. and was flabby, cyanosed and dyspnoeic. The temperature was $101^{\circ} \mathrm{F}$., the pulse extremely rapid and the respiration rate 60 per minute. The ribs were markedly beaded, and the epiphyses enlarged. The Wassermann reaction was negative (also after provocative injection).

Progress. The infant was given intranasal oxygen and stimulants on admission, vitamin $\mathbf{B}$, 2000 units daily for three days, and atropine. The general condition improved. The infant was 
$\mathrm{X}$-rayed five days after admission and then given Adexolin minims 10 t.d.s., Mead's mineral tablets 1 t.d.s., and ten treatments with ultra-violet light.

RADIOLOGICAL EXAMINATION. July 1, 1939. Severe active rickets.

July 10, 1939 . Improvement.

August 9, 1939. Well-marked improvement.

Diagnosis. Rickets and beri-beri; pneumonia.

Case 3. (To show typical appearance of rickets and malnutrition.)

HistoRy. A Chinese female infant, aged fourteen months, was admitted on July 26, 1939, had been fed from birth on sweetened condensed milk and 'bubo' (soft boiled rice).

FAMILY HISTORY. The father was alive and healthy; he was a coolie earning 10 to 18 S.S. dollars a month. The mother was alive and healthy

Fig. 3.-Case 3. Advanced rachitic changes.

and ate white rice. The oldest child, aged six years, and the second child, aged four years, were described as ' well '; the third child was the patient; a fourth child had died, aged one month.

EXAMINATION ON ADMISSION. The infant was emaciated, weighing $10 \mathrm{lb}$. $5 \mathrm{oz}$. The abdomen was distended; ascarides were present. The ligaments were lax, kyphosis was present, and the ribs showed very marked beading. There was no craniotabes.

Progress. Treatment consisted of general measures, Mead's mineral tablets and cod liver oil; calciferol, $6 \mathrm{mgm}$., was given intramuscularly. Progress was slow, as the child's power of digestion and assimilation was seriously impaired.

RADIOLOGICAL REPORT. Advanced rachitic changes are present in all long bones, including the ribs; the bone-shadow generally is poor.

Case 4. (Early rickets and terminal pneumonia in an infant, aged 40 days.)

HistORY. A Chinese male infant, aged 40 days, was admitted July 16 to 26,1939 . He had been fed from birth on sweetened condensed milk. Fits and pyrexia had occurred for one day. (Family history was not obtained.)

EXAMINATION ON ADMISSION. The infant was cyanosed, having frequent fits, and weighed $8 \mathrm{lb}$. $2 \mathrm{oz}$. The temperature was $99^{\circ} \mathrm{F}$., the respiration rate 30 , and the pulse 120 per minute. The ribs were beaded and the abdomen prominent; there was no craniotabes. The spleen and liver were not felt. The knee jerks were diminished. The Kahn test was negative.
Progress. The fits were relieved by lumbar puncture and the administration of chloral. The cerebrospinal fluid was normal. The infant was treated with Adexolin minims 5 t.d.s. and Mead's

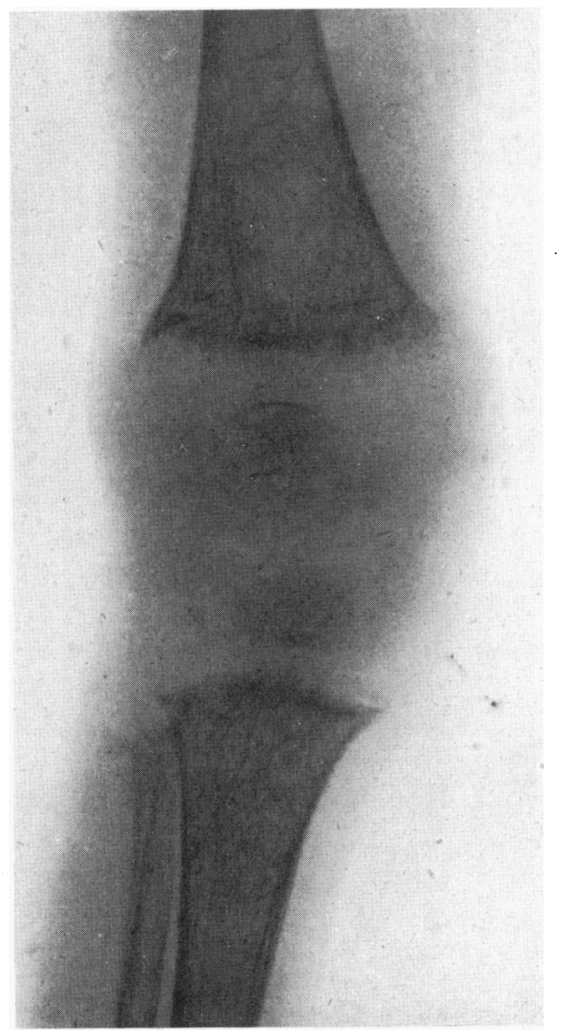

Fig. 4.-Case 3. Advanced rachitic changes at knee.

mineral tablets 1 t.d.s. He developed pneumonia and died.

RADIOLOGICAL REPORT. July 17, 1939. Slight periostitis and some rarefaction, with cupping of ulnar epiphysis.

POST-MORTEM (HISTOLOGICAL) REPORT. The rib shows slight proliferation of the cartilage columns, but the irregularity is not marked. There is increased vascularity of cartilage present with

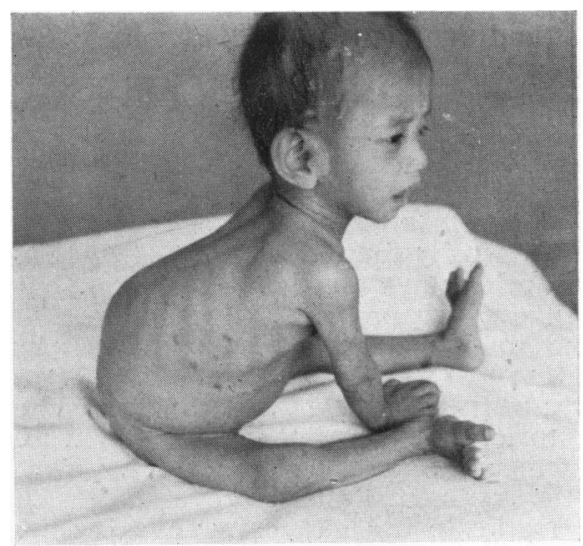

FIG. 5.-Case 3. Beading of ribs, hypotonia, and kyphosis. 
irregular downgrowths of cartilage substance into the marrow. Irregular calcification is seen, and there is an increase of osteoid substance. In the wrist, the cartilage columns show slight irregularity;

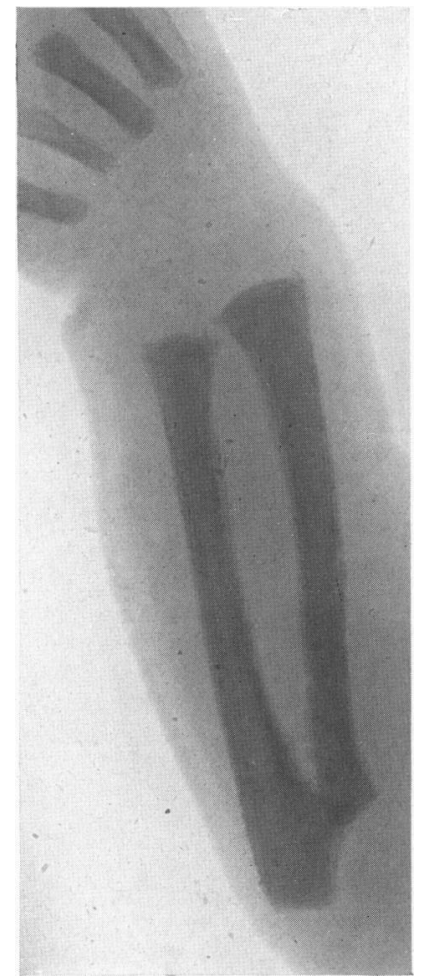

FIG. 6.-Case 4. Slight periostitis and some rarefaction, with cupping of ulnar epiphysis.

there is increased vascularity of the preparatory zone of cartilage and increase of osteoid substance, with irregular calcification. The knee shows similar appearances to those seen in the wrist.

Case 5. (Typical case of rickets: history, $x$-ray and histological report.)

History. A Chinese male infant, aged five months, was admitted May 6 to 31, 1939. According to the Health Nurse's card, the baby was born on December 10, 1938, and was given both the breast and tinned milk until February, 1939; after then he had sweetened condensed milk only. $\mathrm{He}$ was visited five times in his home and attended the welfare centre five times. In March, 1939, he was admitted to hospital for a week with ' lobar pneumonia' (during the absence of the author). $\mathrm{He}$ was subject to attacks of bronchitis and enteritis, and was usually found 'very dirty.' (The Chinese do not believe in washing a sick person.) In May, 1939, he was given Parrish's food and cod liver oil at the welfare centre. (Family history was not obtained.)

EXAMINATION ON ADMISSION. The infant was thin, toxic, and dehydrated, weighing $7 \mathrm{lb} .9 \mathrm{oz}$. The temperature was $101^{\circ} \mathrm{F}$., the pulse rate 150 , and the respiration rate 42 per minute. The ribs were markedly beaded; craniotabes were absent. There were signs of pneumonia at the right base. The Wassermann reaction was negative (also after provocative injection)

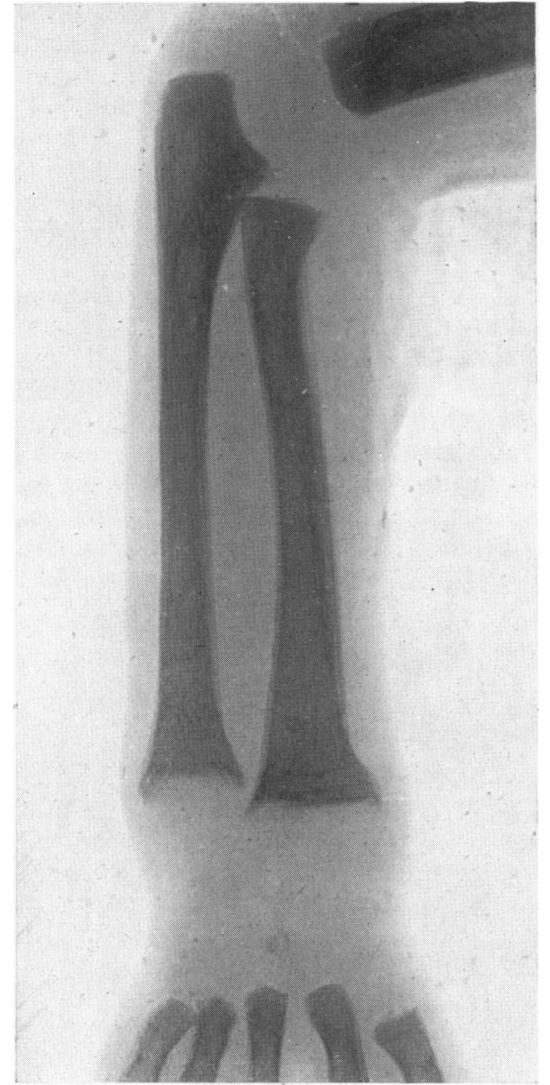

FIG. 7.-Case 5. Flaring and cupping of long bones with symmetrical periostitis.

RADIOLOGICAL EXAMINATION. Marked flaring and cupping of the ends of the long bones, and symmetrical periostitis of all the long bones.

Progress. The infant was given the usual treatment, but developed diarrhoea and died.

POST-MORTEM (HISTOLOGICAL) EXAMINATION. The rib shows marked increase in depth of cartilage columns with great irregularity and distortion of these. The vascularity of the cartilage is increased and there is marked downward proliferation of cartilage substance into the marrow. Irregular areas of calcification and osteoid material are present. The wrist shows much the same picture as the ribs, except that there is no marked increase in the depths and irregularity of the cartilage columns.

Case 6. (To show advanced rachitic changes.)

HISTORY AND FAMILY HISTORY were not obtained.

EXAMINATION ON ADMission. A Chinese male infant, aged eleven months, appeared undernourished and extremely anaemic. The ribs were markedly beaded and a well-marked Harrison's sulcus was present. The epiphyses were enlarged; there was no craniotabes. The teeth were hypoplastic, and the limbs slightly bowed. Pneumonia was present. (The infant died after four days.)

RADIOLOGICAL EXAMINATION. Marked rachitic changes present. The bones were re-X-rayed post mortem. The accompanying figures (fig. 8 to 11) show the advanced rachitic changes, whilst the striations on the skull are similar to those seen in Cooley's anaemia. 


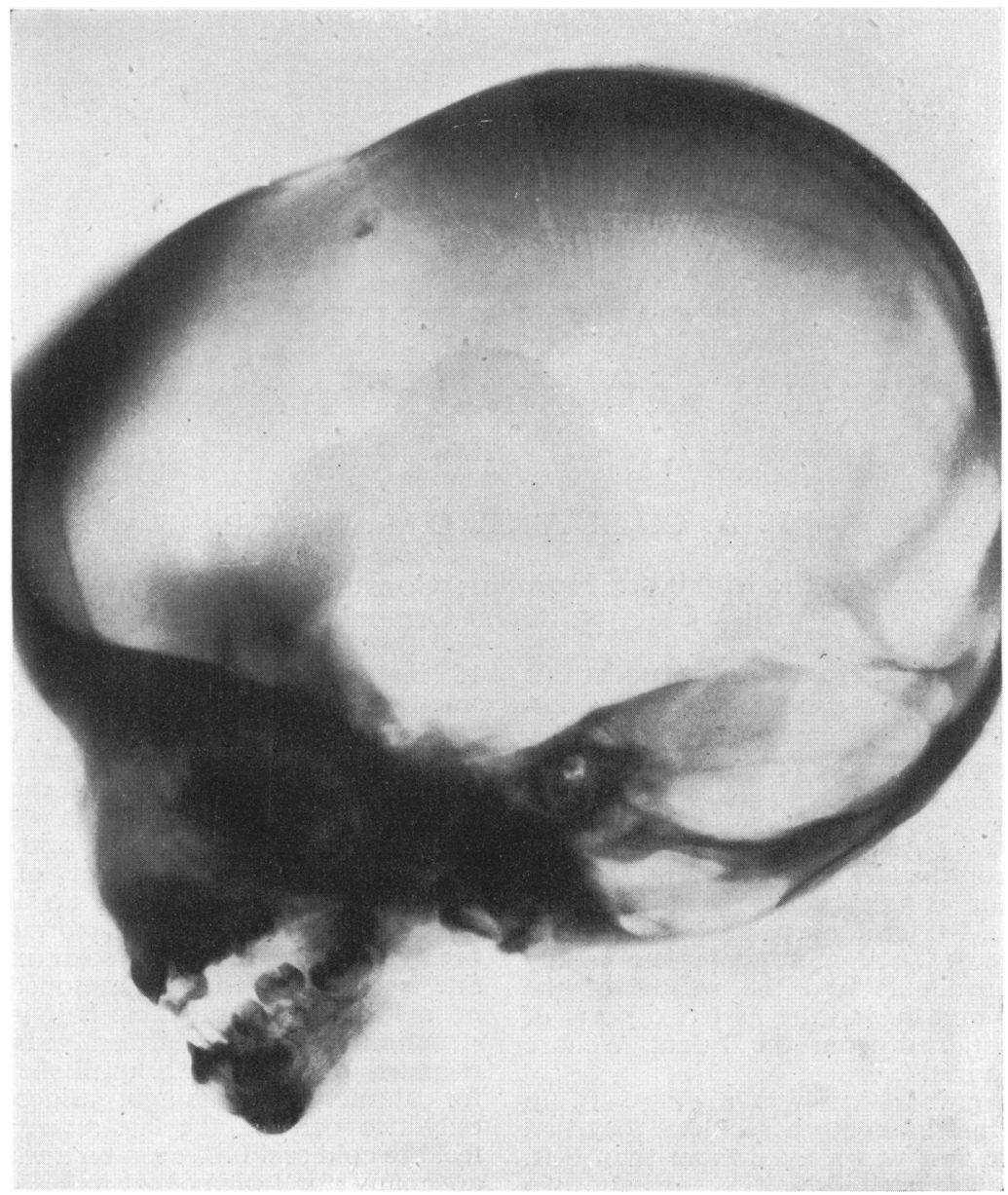

FIG. 8.-Case 6. Skull showing striations resembling those seen in Cooley's anaemia.

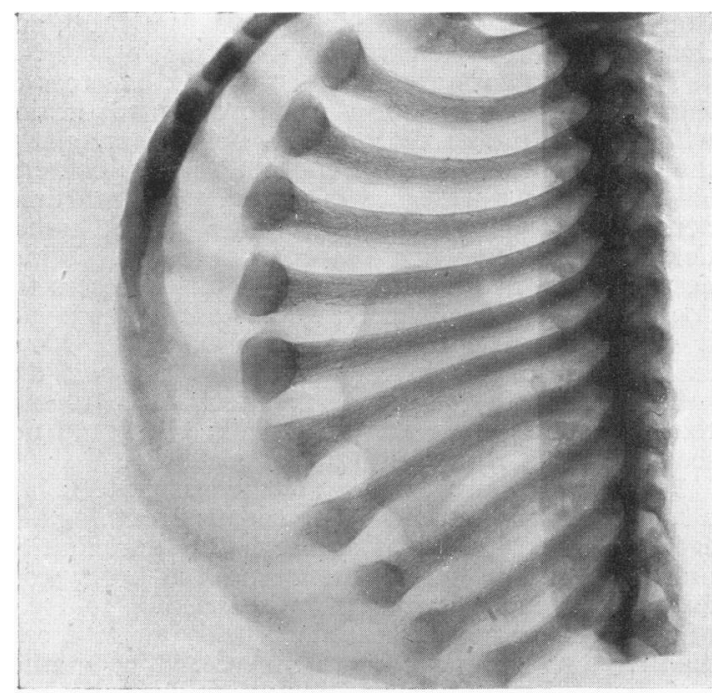

FIG. 9.

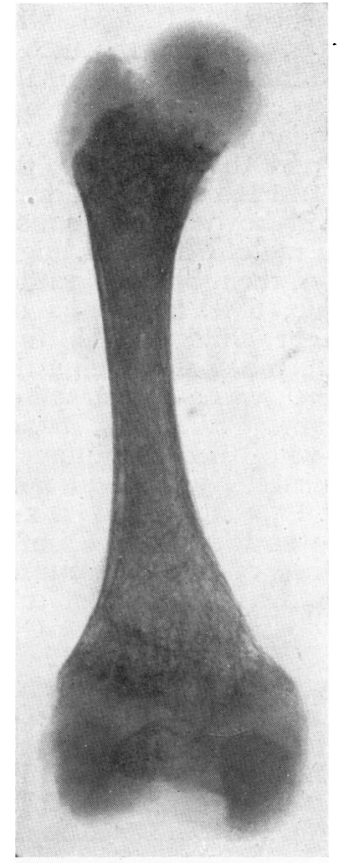

FIG. 10.

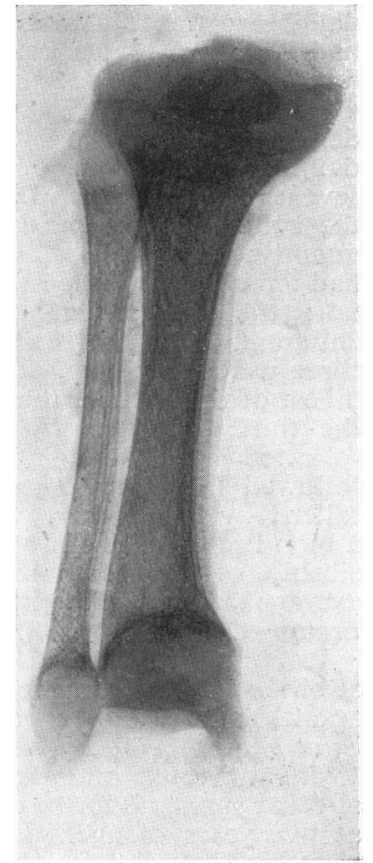

FIG. 11.

Fig. 9.-Case 6. Post-mortem x-ray of costochondral junctions showing advanced rachitic changes. FIG. 10.-Case 6. Post-mortem x-ray of femur (rachitic changes). 